\title{
Physico-Chemical Variation Ontikhur Powder Extracted By Laboratory Grinder and Extraction Machine
}

\author{
Yograj $^{1 *}$, D. Khokhar ${ }^{1}$, S. Patel ${ }^{1}$, P.K. Nishad ${ }^{2}$ and Geetesh Sinha ${ }^{1}$ \\ ${ }^{1}$ Department of Agricultural Processing and Food Engineering, IGKV, Raipur (C.G.), India \\ ${ }^{2}$ ICAR-Central Institute of Agricultural Engineering, NabiBagh, \\ Berasia Road, Bhopal (M.P.), India \\ *Corresponding author
}

\section{A B S T R A C T}

Keywords

Curcuma

angustifolia, Starch,

Extraction method,

Physicochemical

properties

Article Info

Accepted:

17 January 2018

Available Online:

10 February 2018
The starch obtained from the tikhur rhizomes is highly nutritious and easily digestible. In this paper describe the variation of physicochemical properties on tikhur powder extracted from rhizome by two different methods such as laboratory grinder and starch extraction machine. Results shows that the values of physicochemical properties slightly differ in protein and ash but no more significant variation finds. The data of water solubility index and swelling powers of tikhur powder was increased with increasing temperature range from $50-100^{\circ} \mathrm{C}$. In concussion the use of both methods for powder extraction are more useful and economical.

\section{Introduction}

Tikhur (Curcuma angustifolia Roxb.) is an important annual herb belongs to the family of Zingiberaceae, which also contain plants such as ginger and turmeric (Sashikumar, 2007). This species is native to the Indian subcontinent and is more commonly known as East Indian Arrowroot or Narrow leaved turmeric in English, and is called "yaipan" in Manipuri, "tikhur" in Hindi, and "Koova" in Malayalam, Tavaksira in Sanskrit, Tavakila in Marathi, Ararut-kizhagu in Tamil, Keturi Halodhi in Bengali (Patel et al., 2015).
The plant is most commonly found growing wild in Indian especially in the North East and Western coastal plains and hills. Such areas include the states of Maharashtra, Madhya Pradesh, Andhra Pradesh, Himanchal Pradesh, Chhattisgarh, Bihar, Jharkhand, West Bengal, Tamil Nadu and Kerala (Tiwari and Patel, 2013). This species can also be found in Burma, Laos, Nepal and Pakistan (Ravindran et al., 2007). Its major availability is reported in moist deciduous Sal and mixed forest of Madhya Pradesh, Chhattisgarh and Jharkhand (Tiwari and Patel, 2013). At the present time the collection of tikhur rhizomes 
and its traditional and mechanical processing for the extraction of starch is generally done by the tribal farm families residing in and around the forest areas of these regions.

Tikhur rhizome is highly valued as an article of diet. The starch obtained from the dry powdered rhizome forms the chief source of the plant and starch obtained from the rhizomes is highly nutritious and easily digestible, therefore, it is recommended for infants, weak children and invalids. Starch recovery is $12.5 \%$ from the tuber, is in high demand (Wealth of India, 1972). The starch can be consumed by individuals during fast as it is rich in energy. The starch of tikhur is used for the preparation of many sweet meals and herbal dishes like halwa, barfi, jalebi etc. It is used specially during fast (Vrata, Upwas). Farmers also prepare herbal drink "sarbat" through tikhur starch during summer due to its cooling effect (Singh and Palta, 2004).

The present investigation carried out to study the "Physicochemical Variation on tikhur Powder Extracted by Laboratory Grinder and Starch Extraction Machine" was conducted at SV College of Agricultural Engineering and Technology, Raipur, Chhattisgarh.

\section{Materials and Methods}

The study was conducted at SV College of Agricultural Engineering and Technology, Raipur in Agricultural Processing and Food Engineering laboratory during 2016-17. tikhur rhizome was procured from the local market of Dhamtari District of Chhattisgarh and two methods (Laboratory grinder and starch extraction machine) was used for extraction of powder from the tikhur rhizomes (Fig. 1). The analysis of various physicochemical properties such as moisture content, bulk and true density, water solubility index, swelling power, ash content, fat percent, fiber, protein content, carbohydrate and titrable acidity of extracted powder was done in the R.H. Richharia Research Laboratory of the IGKV by using standard techniques.

\section{Physicochemical properties of tikhur powder}

The moisture content was determined by using moisture analyzer (Fig. 2). About five gram $(5 \mathrm{~g})$ of sample was kept in the moisture analyzer at $180^{\circ} \mathrm{C}$. The method was continued till the entire moisture was evaporated.

\section{Bulk density and true density}

Bulk density was determined by filling a measuring cylinder of $100 \mathrm{ml}$ with tikhur powder by pouring it form a certain height, striking off the top level and weighing the contents on a balance. The ratio of weight of the sample and volume occupied by it is expresses as the bulk density. Bulk density of the powder was expressed in $\mathrm{g} / \mathrm{ml}$ was determined using equation (1):

$\mathrm{Db}=\frac{\mathrm{M}}{\mathrm{V}_{0}}$

Where,

$\mathrm{D}_{\mathrm{b}}, \mathrm{M}$ and $\mathrm{V}_{0}$ are bulk density in $\mathrm{g} / \mathrm{ml}$, mass of powder in $\mathrm{g}$ and bulk volume of powder in $\mathrm{ml}$, respectively

True density was determined by adding $5 \mathrm{~g}$ of starch powder in $25 \mathrm{ml}$ toluene in $100 \mathrm{ml}$ measuring cylinder. The final volume was noted and true volume of starch powder sample was determined from the difference. The true density of the sample was expressed as the ratio of weight of sample and the true volume. True density was calculated using equation (2):

True density $\left(\frac{\mathrm{g}}{\mathrm{m}}\right)=\frac{\text { Weight of sample }(\mathrm{g})}{\text { True volume }(\mathrm{ml})}$ 


\section{Ash content}

Ash content was determined according to AOAC (1995) procedure. $2 \mathrm{~g}$ of sample was taken in a silica crucible and weighed. It was made to ash in a muffle furnace at $600^{\circ} \mathrm{C}$ for 3 to 4 hours. The crucible was cooled in the desiccators and weighed, and the value for ash content was calculated by using the following expression (3):

\section{Ashcontent, \%}

$=\frac{\text { Weight of ash }+ \text { crusible }- \text { Weight of crusible }}{\text { Initial weight of sample }} \times 100$

\section{Fat content}

The total fat content was calculated by the Soxhlet method as described in the AOAC (1995) method. In this technique $2 \mathrm{~g}$ of sample was taken into the thimble. With the help of anhydrous ether (boiling point $60-$ $80^{\circ} \mathrm{C}$ ) and "Socs Plus" (extraction equipment) fat was extracted. The amount of fat was calculated by the following formula (4):

Fat content, $\%=\frac{B-A}{W} \times 100$

Where;

A, B and Ware initial weight of beaker, final weight of beaker andweight of sample in $g$

\section{Dietary fiber}

The total dietary fiber, a measure of the sum of insoluble and soluble dietary fiber, based on digestion of food samples (1g) which was taken into the crucibles was analysed using fibre plus system (Pelican make) with standard method.

$$
\begin{aligned}
& \text { Fiber, } \% \\
& =\frac{\text { Weight of crusible plus fiber }- \text { Weight of empty crusible }}{\text { Initial weight of sample }} \times 100
\end{aligned}
$$

\section{Protein}

Protein of the tikhur powder was determined by Kjeldahl method (Jackson, 1958) by digesting $0.3 \mathrm{~g}$ of powder sample in $10 \mathrm{ml}$ conc. $\mathrm{H}_{2} \mathrm{SO}_{4}$ and catalyst mixture of potassium sulphate and copper sulphate in 5:1 ratio followed by distillation and titration. The obtained value of nitrogen was multiplied with the factor 6.25 to get powder protein per cent.

The amount of protein was calculated by following formula (6):

Nitrogen $=\frac{14.01 \times 0.1 \mathrm{~N} \times(\mathrm{TV}-\mathrm{BV}) \times 100}{\mathrm{~W} \times 1000}$

Protein $\%=\%$ Nitrogen $\times 6.25$ (for Food samples)

Where,

14.01 = Ammonia's molecular weight

$0.1 \mathrm{~N}=$ Titration solution's normality

$\mathrm{TV}$ and $\mathrm{BV}=$ Titer value and blank value

\section{Total carbohydrate}

The total carb(4)ydrates were calculated by the by AOAC (1995) method. After determining the percentage of moisture, protein, and fat and total ash content in the developed sample it was calculated as follows (7):

Total carbohydrate, $\%=\{100-(\mathrm{A}+\mathrm{B}+\mathrm{C}+\mathrm{D})\}$ $\%$

Where,

$\mathrm{A}, \mathrm{B}, \mathrm{C}$ and D are moisture content, protein, fat and ash content in per cent, respectively

\section{pH value}

One gram $(1 \mathrm{~g})$ of the individual starch was added to $100 \mathrm{ml}$ of distilled water and the $\mathrm{pH}$ was determined in an electronic $\mathrm{pH}$ meter. 


\section{Titrable acidity}

The titrable acidity of tikhur powder was determined as per the procedure of Ranganna (1997). The powder $(10 \mathrm{~g})$ was diluted with $200 \mathrm{ml}$ of lukewarm distilled water and titrated against $0.1 \mathrm{~N}$ sodium hydroxide using phenolphthalein as an indicator. Following formula (8) used to determined titrable acidity:

Percentage titrable acidity $=\frac{T \times N \times V \times E \times 100}{V \times W \times 1000}$

Where;

$\mathrm{T}, \mathrm{N}, \mathrm{E}, \mathrm{V}, \mathrm{v}$ and Ware titrable value in $\mathrm{ml}$, normality of alkali, equivalent weight of reagent in $\mathrm{g}$, volume made up in $\mathrm{ml}$, Volume of sample in $\mathrm{ml}$ and weight of sample in $\mathrm{g}$, respectively.

\section{Water solubility index (WSI) and Swelling power}

The solubility and swelling index of starch were determined using the method reported by Sharlina et al., (2017), with slight modifications. $0.5 \mathrm{~g}$ of dry starch was transferred into avial containing $10 \mathrm{~mL}$ of distilled water and stirred using amagnetic stirrer for $30 \mathrm{~min}$ before being heated at 50 , $60,70,80,90$ and $100{ }^{\circ} \mathrm{C}$ for $30 \mathrm{~min}$. Then, the starch slurry was cooled toroom temperature, transferred to a centrifuge tube and centrifuged at $1500 \mathrm{rpm}$ for $30 \mathrm{~min}$. Different starch slurries were used for each of the temperatures.

The supernatant from the centrifuge tube was carefully decanted into another vial, and wet starch precipitate was weighed after it was drained for $10 \mathrm{~min}$. The supernatant was dried in an oven at $105{ }^{\circ} \mathrm{C}$ until a constant weight was reached. The analysis was performed in triplicate. The solubility and swelling power were calculated using Eqs. (9) and (10).

Water solubility index $(\%)=\frac{\text { weight of dissolved starch from heated solution }}{\text { Weight of starch sample }} \times 100(9)$

Swelling power $=\frac{\text { Weight of starch paste }}{\text { Weight of dry starch sample }} \times 100$

\section{Results and Discussion}

\section{Vitamin B6 in areca nut}

The results of Vitamin B-6 in areca samples of Karnataka have been presented in table 1 and 2. In Shimoga district high amount of vitamin B6 was estimated in Anwatti and Kasaba hoblies (52.33 and $47.67 \mathrm{ppm}$ ) of Soraba taluk and $10 \mathrm{ppm}$ of vitamin B6 was determined in different hoblies of Shimoga district.

In Chikkamagalur district also $10 \mathrm{ppm}$ of vitamin B6 was determined in different hoblies. The high amount of vitamin B6 was determined in Kigga hobli (72.67 ppm) of Koppa taluk followed by Sakharayapattana hobli of Kadur taluk (69.00 ppm). High amount of Vitamin B6 was estimated in Bilichodu hobli $(84.67 \mathrm{ppm})$ followed by Santhebennuru hobli $(55.00 \mathrm{ppm})$ of Davanagere district.

High content i.e., 72.67 and 68.33 ppm was estimated in Turuvanooru and Bharamasagar hoblies of Chitradurga district. In Dakshina Kannada district highest amount of vitamin B6 was determined in Upinangadi (91.33 ppm) and Surathkal (91.00 ppm) hoblies of Puttur and Mangalore taluks respectively. In Udupi district high amount of vitamin B6 was determined in Ajekaru hobli (81 ppm) followed by Karkala hobli (56 ppm) of Udupi district (Table 1). 
Table.1 Physicochemical properties of tikhur powder

\begin{tabular}{|r|l|c|c|}
\hline S. No. & \multicolumn{1}{|c|}{ Properties } & $\begin{array}{c}\text { Laboratory } \\
\text { Grinder }\end{array}$ & $\begin{array}{c}\text { Starch } \\
\text { Extraction } \\
\text { Machine }\end{array}$ \\
\hline 1. & Moisture content, (\%) & 12.95 & 12.70 \\
\hline 2. & Bulk density, (g/ml) & 0.79 & 0.81 \\
\hline 3. & True density, (g/ml) & 1.64 & 1.63 \\
\hline 4. & Ash content, (\%) & 0.87 & 0.96 \\
\hline $\mathbf{5 .}$ & Fat content, (\%) & 0.44 & 0.42 \\
\hline $\mathbf{6 .}$ & Crude fiber content, (\%) & 0.64 & 0.79 \\
\hline 7. & Protein content, (\%) & 1.34 & 1.49 \\
\hline $\mathbf{8 .}$ & Total carbohydrate, (\%) & 85.40 & 85.43 \\
\hline 9. & pH value & 7.30 & 7.40 \\
\hline 10. & Titrable acidity, (\%) & 0.65 & 0.61 \\
\hline
\end{tabular}

Table.2 Water solubility index and Swelling power of tikhur power at different temperature

\begin{tabular}{|c|c|c|c|c|}
\hline \multirow{2}{*}{ Temperature } & \multicolumn{2}{|c|}{ Swelling power } & \multicolumn{2}{c|}{ Water solubility index } \\
\cline { 2 - 5 } & $\begin{array}{c}\text { Laboratory } \\
\text { grinder }\end{array}$ & $\begin{array}{c}\text { Starch extraction } \\
\text { machine }\end{array}$ & $\begin{array}{c}\text { Laboratory } \\
\text { grinder }\end{array}$ & $\begin{array}{c}\text { Starch } \\
\text { extraction } \\
\text { machine }\end{array}$ \\
\hline $\mathbf{5 0} \mathbf{C}$ & 2.946 & 3.401 & 8.32 & 8.17 \\
\hline $\mathbf{6 0}^{\mathbf{0}} \mathbf{C}$ & 3.663 & 4.054 & 12.34 & 13.69 \\
\hline $\mathbf{7 0}^{\mathbf{0}} \mathbf{C}$ & 6.579 & 7.946 & 23.35 & 27.29 \\
\hline $\mathbf{8 0}^{\mathbf{0}} \mathbf{C}$ & 7.359 & 9.988 & 48.05 & 48.59 \\
\hline $\mathbf{9 0} \mathbf{C}$ & 11.202 & 12.472 & 68.96 & 71.12 \\
\hline $\mathbf{1 0 0}^{\mathbf{0}} \mathbf{C}$ & 13.976 & 16.979 & 81.16 & 80.76 \\
\hline
\end{tabular}




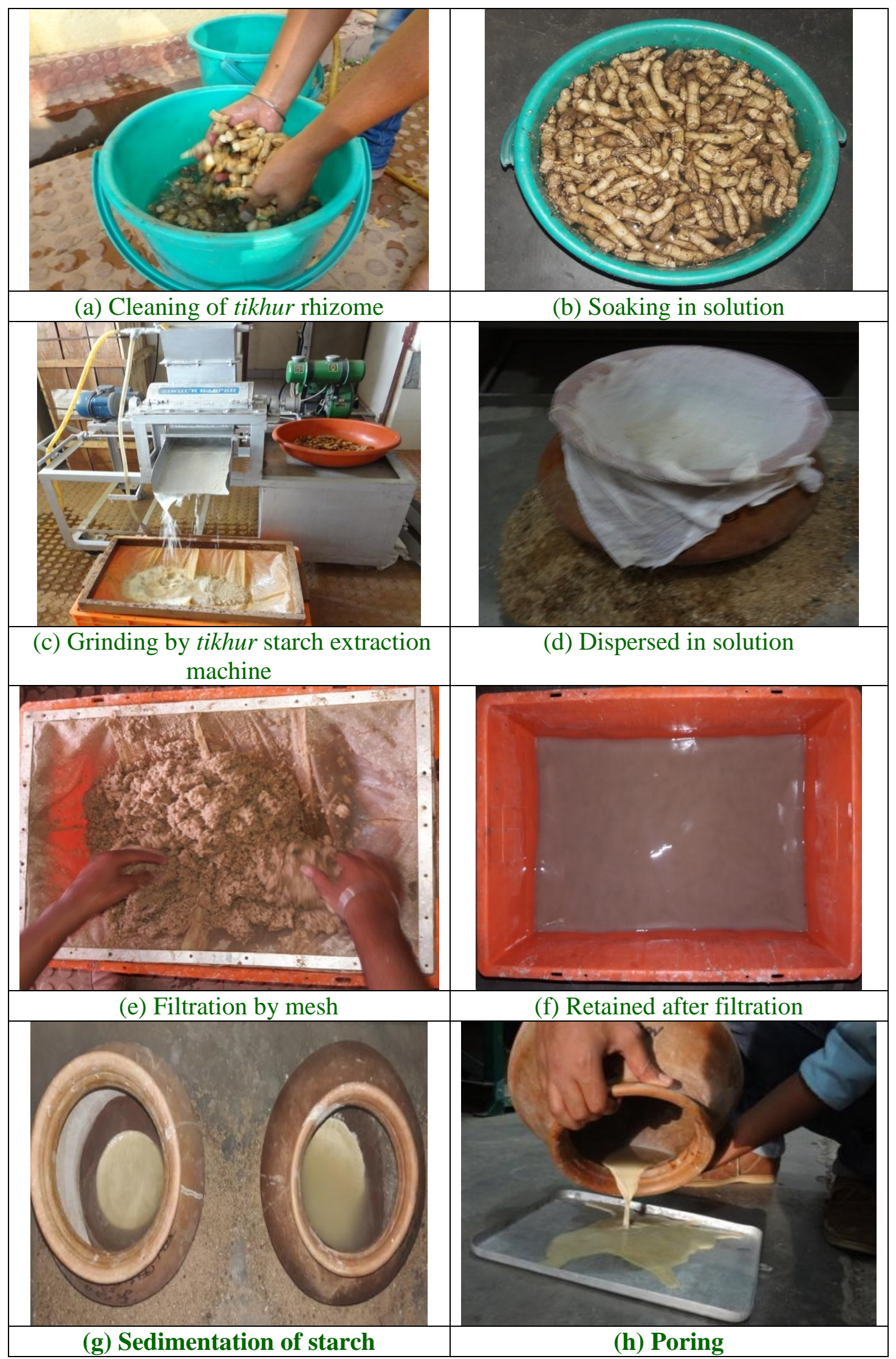



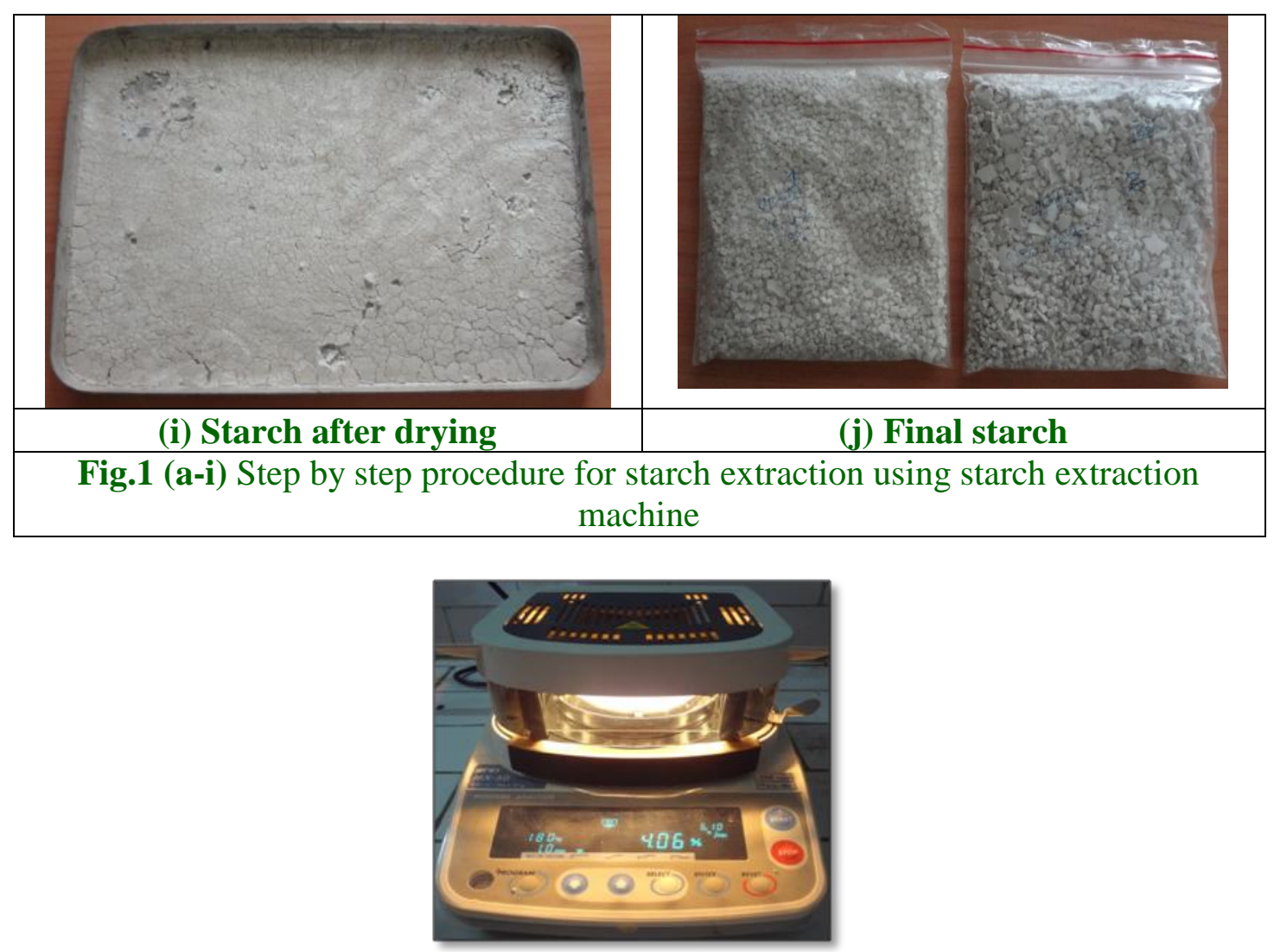

Fig.2 Determination of moisture content (Moisture analyzer)

The result of physicochemical analysis of the tikhur powder extracted by laboratory grinder and starch extraction machine is presented in Table 1. The average moisture content of tikhur powder was found to be $12.83 \%$ (wb). Ellis et al., (2003) reported that the good quality starch should have moisture content of in the range of $10-13.5 \%$ to ensure better shelf life. The results of physico-chemical analysis of tikhur powder indicated that it contain about on an average $1.42 \%$ protein, $0.43 \%$ fat, $0.72 \%$ fiber, $85.41 \%$ carbohydrate and $0.92 \%$ ash, respectively. However, it is possible to have different results based on the location environmental condition soil fertility etc.

Similarly results reported by Paikra et al., (2017) and Patel et al., (2015) fortikhur powder. Tiwari and Patel (2013) reported the proximate composition at $13 \%$ moisture content was found to be $1.6 \%$ protein, $0.9 \%$ fat, $84 \%$ carbohydrate and $1.2 \%$ ash, respectively. Deshpande, (2008) also reported that the rhizomes of tikhur contains $69-70 \%$ moisture, starch $25-30 \%$, crud protein $1.6 \%$, fat $0.2 \%$, sugar and dextrins $2.1 \%$, crude fibre $3.9 \%$ and ash $0.9 \%$, respectively.

Starch extraction method have slightly rich in every constitute especially in protein and ash content about 0.15 and 0.12 percentage then laboratory grinding method and have no significant variation found. The details are given below in the Table 1 .

\section{Water solubility index and Swelling power}

From Table 2 shows the water solubility index and swelling powers of tikhur starch at temperature in the range of $50-100^{\circ} \mathrm{C}$ by $10^{\circ} \mathrm{C}$ intervals. It was depicted that the water solubility index and swelling power of tikhur starch increases with increase in temperature. The water solubility index of starch obtained 
from laboratory grinder and tikhur starch extraction machine was higher $81.496 \%$, $81.31 \%$ at $100^{\circ} \mathrm{C}$ temperature and lower $6.65 \%, 8.85 \%$ respectively, at $50^{\circ} \mathrm{C}$. The swelling power of starch obtained from laboratory grinder was highest $13.98 \mathrm{~g} / \mathrm{g}$, at $100^{\circ} \mathrm{C}$ temperature whereas tikhur extracted from the tikhur starch extraction machine was found $16.98 \mathrm{~g} / \mathrm{g}$ respectively, at $100^{\circ} \mathrm{C}$ temperature. Swelling power of starch depends on the capacity of starch molecules to hold water through hydrogen bonding. The high swelling power results into high digestibility and ability to use starch (Nuwamanya et al., 2011) and also show that the swelling power of starch extracted with chemical treatment is differ from control.

Similar some researchers have reported an increase in water solubility index and swelling power with increase in temperature for tikhur (Rani and Chawhaan, 2012, Kumari et al., 2017), tuber (Babu and Parimalavalli, 2012) and ginger (Michael et al., 2014).

In conclusion, the starch obtained from thetikhur rhizomes is highly nutritious and easily digestible. In this paper describe the variation of physicochemical properties on tikhur powder extracted from rhizome by two different methods such as laboratory grinder and starch extraction machine. Results shows that slightly differ in protein and ash but no more significant variation finds. The data of water solubility index and swelling powers of tikhur powder was increased with increasing temperature range from $50-100^{\circ} \mathrm{C}$.In concussion the use of both methods for powder extraction are more useful and economical.

\section{References}

AOAC, 1995.Official Methods of Analysis 16th Edn. J. Association of Official Analytical. Chemists, Washington DC,
37: 1-10.

Babu, A. Surendra and Parimalavalli, R. 2012. Functional and Chemical Properties of Starch isolated from Tubers. International Journal of Agricultural and Food Science. Universal Research Publications. Available online at http://www.urpjournals.com

Deshpande, D.J. 2008. A Handbook of Herbal Remedies. Agribios Pub, Jodhpur, India, 403-404.

Ellis, W.O. Oduro, I Barimah, J and Otoo, J.A. Quality of starch from six Japanese sweet potato varieties in Ghana. African Journal of Root and Tuber Crops. 5(2): 38-41, 2003.

Kumari R, Shrivastava SL, Mishra HN and Murlidhar Meghwal. 2017. Physicochemical and functional properties of Curcuma angustifolia (Tikhur) - An underutilized starch. The Pharma Innovation Journal 2017; 6(7): 114-119

Michael, Afolayan, Macham David, Bwai, Maryam Shu'aibu, Ibrahim and Abayomi, Orishadipe 2014. Physicochemical, proximate and phytochemical evaluation of starch from Eleusine coracana L. (finger millet). Pharmaceutical and biological evaluations. 2(4): 2394-0859.

Nuwamanya E, Baguma Y, Wembabazi E, Rubaihayo P. A comparative study of the physicochemical properties of starches from root, tuber and cereal crops. African Journal of Biotechnology, 2011; 10(56):1201812030.

Paikra C, Patel S and Parganiha D. Physico Chemical Properties of Tikhur Starch Powder Obtained From Different Extraction Method. Trends in Biosciences 10 (8), 2017 1626-1629

Paikra CK, Patel S, Naik RK, Ram DS. Performance evaluation of tikhur 
(Curcuma Angustifolia) starch extraction machine. Indian Journal of Science Research and Technology. 2013; 2(5): 34-38.

Patel S, Tiwari S, Pisalkar PS, Mishra NK, Naik RK, Khokhar D. Indigenous processing of Tikhur (Curcuma angustifolia Roxb.) for the extraction of starch in Baster, Chhattisgarh. Indian Journal of Natural Products and Resources. 2015; 6(3):213-220.

Ranganna S. Handbook of analysis and quality control for fruit and vegetable products. New Delhi: Tata Mc-Graw Hill; 1997. pp. 4-5.

Rani A, Chawhaan PH. Extraction and scanning electron microscopic studies of Curcuma angustifolia Roxb.starch. Indian Journal of Natural Products Resources, 2012; 3(3):407-10.

Ravindran $\mathrm{P} \quad \mathrm{N}$, Nirmal Babu $\mathrm{K}$ and Sivaraman K, Turmeric: The genus Curcuma, CRC Press, Taylor and Francis Group, N.Y, 2007, 504.
Sasikumar B, Genetic resources of Curcuma: Diversity, characterization and utilization, Plant Genet Resour: Characteriz, Utiliz, 2005, 3(2), 230-251. Sharlina MSE, Yaacob WA, Lazim AM, Fazry S, LimSJ, Abdullah S et al. Physicochemical Properties of Starch from Dioscorea pyrifolia tubers. Food Chemistry, 2017; 220:225-232.

Singh R, Palta A. Foods and beverages consumed by abujhmarias - a primitive tribe of Bastar in Chhattisgarh. Tribal Health Bull.2004; 10:33-40.

Tiwari S, Patel S, Physico-chemical variation on tikhur powder obtained from mother and finger rhizome, J Plant Developm, Sci, 2013, 5(2), 139-141.

Tiwari S, Patel S. A comparative study of tikhur traditional and partial mechanical processing and cost economics. International Journal of Agricultural Engineering. 2013; 6(1):213-215.

\section{How to cite this article:}

Yograj, D. Khokhar, S. Patel, P.K. Nishad and Geetesh Sinha. 2018. Techniques for Determination of Vitamin $\mathrm{B}_{6}$, Vitamin C and Variability in Areca Nut (Areca catechu) Samples of Karnataka, India. Int.J.Curr.Microbiol.App.Sci. 7(02): 1940-1948. doi: https://doi.org/10.20546/ijcmas.2018.702.233 